\title{
Développement politique et environnemental (perspective de la CNUCED)
}

Entwicklungspolitische Gedanken zum Problemkreis Umwelt und Entwicklung im Vorfeld der UNCED

\section{Anne Bichsel}

\section{OpenEdition}

\section{Journals}

Édition électronique

URL : http://journals.openedition.org/aspd/1586

DOI : $10.4000 /$ aspd. 1586

ISSN : 1663-9669

Éditeur

Institut de hautes études internationales et du développement

Édition imprimée

Date de publication : 1 janvier 1992

Pagination : 189-197

ISSN : 1660-5934

Référence électronique

Anne Bichsel, « Développement politique et environnemental (perspective de la CNUCED) », Annuaire suisse de politique de développement [En ligne], 11 | 1992, mis en ligne le 19 mai 2013, consulté le 08 septembre 2020. URL : http://journals.openedition.org/aspd/1586 ; DOI : https://doi.org/10.4000/ aspd. 1586

Ce document a été généré automatiquement le 8 septembre 2020

(c) The Graduate Institute / Geneva 


\section{Développement politique et environnemental (perspective de la CNUCED)}

Entwicklungspolitische Gedanken zum Problemkreis Umwelt und Entwicklung im Vorfeld der UNCED

\section{Anne Bichsel}

\section{NOTE DE L'ÉDITEUR}

Lire l'article original en allemand dans Schweizerisches Jahrbuch für Entwicklungspolitik :

« Entwicklungspolitische Gedanken zum Problemkreis Umwelt und Entwicklung im Vorfeld der UNCED ", http://sjep.revues.org/1381. 